\title{
Isolation and characterization of endophytic bacteria of coffee plants and their potential in caffeine degradation
}

\author{
F. V. Nunes \& I. S. de Melo \\ Laboratory of Environmental Microbiology, \\ Embrapa Environment Jaguariúna, SP, Brazil
}

\begin{abstract}
The plant kingdom is colonized by a diverse array of endophytic bacteria, which form a non-pathogenic relationship with their hosts. Endophytic bacteria may confer benefits to the plant, and the benefits may be reciprocal, resulting in an enhanced symbiotic system for specific plant characteristics. The objective of this study was to isolate endophytic bacteria from coffee (Coffea arabica and $C$. robusta) and evaluate their potential in degrading caffeine. The isolates were identified by partial 16S rDNA sequence analysis and by FAME and the analysis of biodegradation of caffeine was carried out by HPLC. As a result, 252 bacterial strains were isolated, with most of them belonging to the species Bacillus lentimorbus, B. megaterium, B. subtilis, B. cereus, Pseudomonas putida, P. chlororaphis, Pantoea ananatis, P. agglomerans, Stenotrophomonas malthophilia, Kluyvera cryocrescens, Kocuria kristinae etc. Approximately $20 \%$ of the bacterial strains showed the ability to grow in the presence of high concentrations (5.000 mg. $\left.\mathrm{L}^{-1}\right)$ of caffeine and two Pseudomonas putida strains completely degraded the alkaloid, showing the potential of endophytic bacteria in decaffeination processes.
\end{abstract}

Keywords: endophytic microorganisms, caffeine, coffee, biodegradation.

\section{Introduction}

Endophytes are microorganisms that live within the tissues of healthy plants where they cause symptomless infections. Their significance to the host is still 
unclear; pathogens as well as non-pathogens can live endophytically. Endophytic bacteria can contribute to the health, growth and development of plants. Plant growth promotion by endophytic bacteria may results from direct effects such as the production of phytohormones or by providing the host plant with fixed nitrogen or the solubilization of soil phosphorus and iron (Glick [1]; Shishido et al. [2]; Kinkel et al. [3]; Sturz et al. [4]). Some endophytic microorganisms have the ability to grow and degrade many xenobiotics. Several studies were carried out to investigate the use of caffeine, as a source of energy for microorganisms. The fungi Penicillium and Aspergillus and the bacteria Pseudomonas are the most frequent caffeine - degrading genera. (Asano et al. [5]; Kurtzman and Shwimmer [6]). The objective of this study was to identify endophytic bacteria from coffee and evaluate their potential to degrade caffeine.

\section{Material and methods}

\subsection{Isolation of endophytic bacteria}

Leaves, stems and roots of healthy plants of Coffea arabica and C. robusta were surface sterilized with ethanol $70 \%$ per 1 min., sodium hipoclorite $2,5 \%$ per 20 min.; and then in ethanol $70 \%$ per 30 sec., following three successive washes in distilled sterilized water. The fragments $(1 \mathrm{~cm})$ were transferred to tryptic soyagar medium. The cultures were incubated at $28^{\circ} \mathrm{C}$ for seven days and the colonies were purified and stored in glycerol at $-80^{\circ} \mathrm{C}$.

\subsection{Strain identification}

Isolated strains were screened for the selection of caffeine-resistant strains. Each strain was identified by analysis of fatty acids methyl-esters (FAME) using the Microbial Identification System developed by Microbial ID (MIDI, Neward, DE) and by $16 \mathrm{~S}$ rDNA sequence analysis.

\subsection{Biodegradation of caffeine}

The dissipation of caffeine by endophytic bacteria was monitored in mineral medium (Czapeck) supplemented with methylxanthine (5 g.. $\left.\mathrm{L}^{-1}\right)$. The analysis of caffeine was carried out on a Shimadzu 10 AS-UP HPLC with photodiode array detector and inertsil 5 ODS-3 $(5 \mu \mathrm{m}, 150 \times 4,6 \mathrm{~mm})$ column. The mobile phase was acetic acid/ acetronitrile $(90: 10, \mathrm{v} / \mathrm{v})$, with a flow rate of $1,0 \mathrm{~mL} \mathrm{~min}{ }^{-1}$, by an isocratic system.

\section{Results and discussion}

A total of 252 endophytic bacteria were isolated from coffee, with most of them assigned to the genera Bacillus, Pseudomonas, Pantoea, Enterobacter, Stenotrophomonas, Kluyvera and Kocuria. Approximately $20 \%$ of the bacterial strains showed the ability to grow in the presence of high concentrations (5.000 mg L $\left.\mathrm{L}^{-1}\right)$ of caffeine. Fig. 1 and 2 illustrate the growth of different strains 
in Czapeck medium supplemented with $5.000 \mathrm{mg} \mathrm{L}^{-1}$ of 1,3,7-trimethylxanthine. It was observed that two Pseudomonas putida strains, O1G and 13R presented the ability to grow in high concentration of caffeine. It is also shown that Bacillus lentimorbus (54G), Enterobacter sp. (111G), Alcaligenes xylosoxydans $(06 \mathrm{~F})$ and $B$. megaterium (45R and 51R) grew in medium supplemented with caffeine $\left(5.000 \mu \mathrm{g} \cdot \mathrm{mL}^{-1}\right)$.

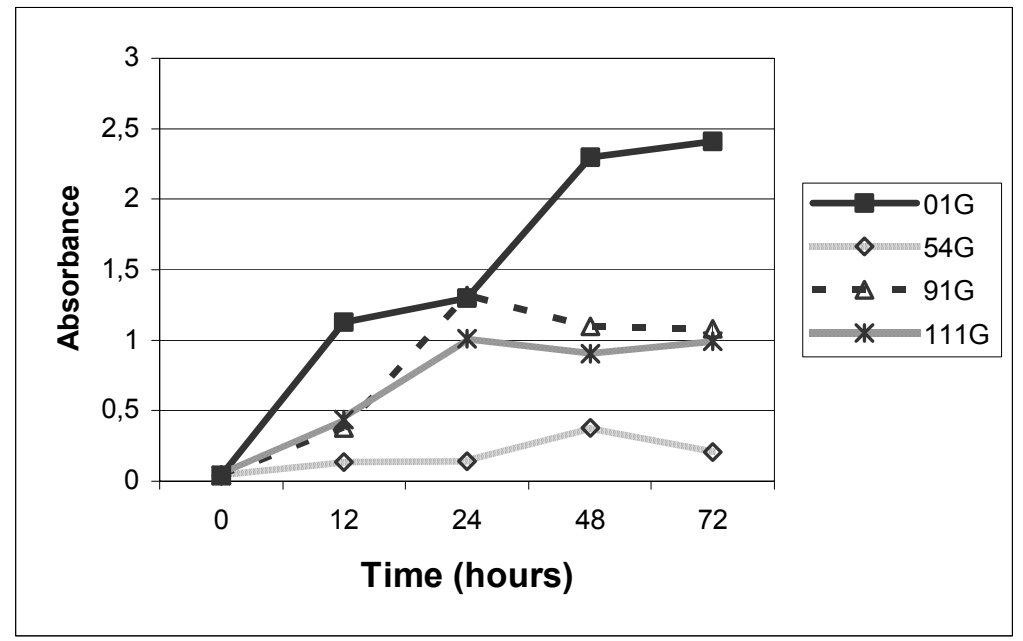

Figure 1: Growth of endophytic bacteria, isolated from coffee stems, supplement with caffeine (5.000 $\left.\mathrm{mg} \mathrm{L}^{-1}\right)$ : Pseudomonas putida (01G), Bacillus lentimorbus (54G), Escherichia coli $(91 \mathrm{G})$ and Enterobacter sp. (111G).

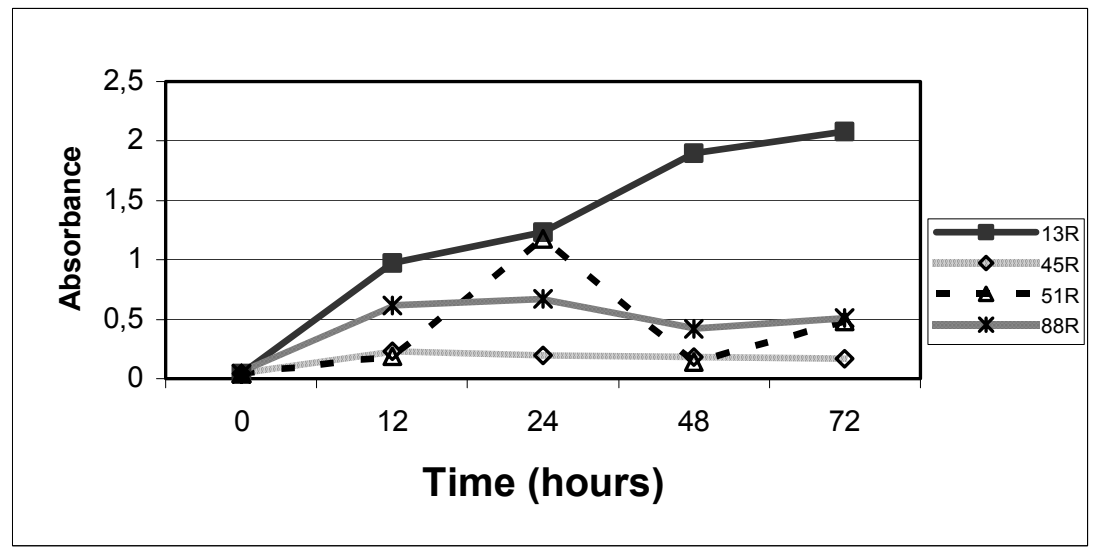

Figure 2: Growth of endophytic bacteria, isolated from coffee roots in liquid medium supplemented with caffeine (5.000 $\left.\mathrm{mg} \mathrm{L}^{-1}\right)$ : Pseudomonas putida (13R), Bacillus megaterium (45R), Bacillus megaterium (51R) and Bacillus sp. (88R). 
Twenty endophytic bacterial strains grew in liquid medium containing concentrations as high as $0.05 \mathrm{M}$ caffeine. Growth was accompanied by complete removal of caffeine from culture medium. Two Pseudomonas putida strains completely degraded the alkaloid (table 1), showing the potential of endophytic bacteria in decaffeination processes. The other bacterial strains evaluated did not metabolized the alkaloid. It is verified that caffeine did not inhibited the normal growth of these bacteria. Caffeine is considered toxic for many microorganisms, however, some microorganisms have the ability to grow in the presence of caffeine and the capacity to degrade this alkaloid.

Table 1: Quantification of caffeine degradation by endophytic bacteria isolated from leaves, stems and roots of Coffea arabica and Coffea robusta, carried out by HPLC. The initial concentration of caffeine was $5.000 \mathrm{mg} \mathrm{L}^{-1}$.

\begin{tabular}{|c|c|c|c|}
\hline Treatments & $\begin{array}{l}\text { CAFFEINE } \\
\left(\mathrm{g} 100 \mathrm{~mL}^{-1}\right)\end{array}$ & Treatments & $\begin{array}{l}\text { CAFFEINE } \\
\left(\mathrm{g} 100 \mathrm{~mL}^{-1}\right)\end{array}$ \\
\hline Control & 0,5809 & 147G-Acinetobacter sp. & 0,6571 \\
\hline 13R - Pseudomonas putida & $\mathbf{0 , 0 0 0 0}$ & 54G-Bacillus lentimorbus & 0,5961 \\
\hline 01G - Pseudomonas putida & 0,0000 & $11 \mathrm{G}-*$ & 0,6076 \\
\hline 06F-Alcaligenes xylosoxydans & 0,6418 & 16F-Bacillus cereus & 0,6215 \\
\hline $12 \mathrm{~F}-$ Pandoraea sp. & 0,6216 & 43G-Pseudomonas sp. & 0,6321 \\
\hline 114R-P.putida & 0,6278 & $\begin{array}{c}\text { 167G-Stenotrophomonas } \\
\text { maltophilia }\end{array}$ & 0,6259 \\
\hline 45R-Bacillus megaterium & 0,6078 & $\begin{array}{c}\text { 100G- Stenotrophomonas } \\
\text { maltophilia }\end{array}$ & 0,6542 \\
\hline 7F- Pantoea agglomerans & 0,5997 & $152 \mathrm{G}-*$ & 0,6168 \\
\hline 51R-Bacillus megaterium & 0,6370 & 129G- Ochrobactrum sp. & 0,6472 \\
\hline 88R-Bacillus sp. & 0,6184 & 91G- Escherichia coli & 0,6049 \\
\hline $\begin{array}{l}\text { 07G- Pseudomonas } \\
\text { chlororaphis }\end{array}$ & 0,6357 & & \\
\hline
\end{tabular}

*- Bacteria not identified.

One of these strains of Pseudomonas putida, strains 13R, presented high pectinolytic activity (pectin lyase) $96,92 \mathrm{nMols}$ of unsaturated product per $\mathrm{mL}^{-1}$. Plant cell walls consist mainly of cellulose, whereas midle lamella, that connects the cells, consists mainly of pectin. Although pectinases might play an important role in plant-microbial interactions and intercellular colonization of roots they have not yet been studied intensively in the endophytic bacteria. 


\section{References}

[1] Glick, B.R. The enhancement of plant growth by free-living bacteria. Canadian Journal of Microbiology, 41: 109-117. (1995).

[2] Shishido, M., Breuil, C., \& Chanway, C.P. Endophytic colonization of spruce by plant growth-promoting rhizobacteria. FEMS Microbiol. Ecol. 29:191-196. 1999.

[3] Kinkel, L.L., Wilson, M., \& Lindow, S.E. Plant species and plant incubation conditions influence variability in epiphytic bacterial population size. Microb Ecol 39: 1- 11. 2000.

[4] Sturz, A.V., Christie, B.R. \& Nowak, J. Bacterial endophytes: potential role in developing sustainable systems of crop production. Crit. Rev. Plant Sci., v. 19, p. 1-30, 2000.

[5] Asano, Y., Komeda. T. \& Yamada. H. Microbial production of theobromine from caffeine. Bioscience Biotechnology Biochemistry, v.57, p.1286-1289, 1993.

[6] Kurtzman, R.H. \& Shwimmer, S. Caffeine removal from growth media by microorganisms. Experientia, 127:481-482, 1971. 